\title{
EKSISTENSI JURNALISME DI ERA MEDIA SOSIAL
}

\section{Oleh : Dian Muhtadiah Hamna ${ }^{1}$ \\ Dosen Ilmu Komunikasi Universitas Muhammadiyah Makassar}

Email : yayan.muhtadiah@gmail.com

\begin{abstract}
Social media that appear lately indeed change the panorama of journalism in Indonesia. Especially concerning the process of gathering news, the process of making news, and the process of spreading the news. Future Journalism-the old and the new-should refer to how people use the news and what they need from journalists.
\end{abstract}

\section{Keywords :}

Journalism, social media

\section{Pendahuluan}

Akses terhadap media telah menjadi salah satu kebutuhan primer dari setiap orang. Itu dikarenakan adanya kebutuhan akan informasi, hiburan, pendidikan dan akses pengetahuan dari belahan bumi berbeda. Kemajuan teknologi dan informasi serta semakin canggihnya perangkat-perangkat yang diproduksi oleh industri seperti menghadirkan "dunia dalam genggaman".

Istilah ini sejajar dengan apa yang diutarakan oleh Thomas L. Friedman (2007) sebagai the world is flat bahwa dunia semakin rata dan setiap orang bisa mengakses apapun dari sumber mana pun. Juga sebagaimana diulas Richard Hunter (2002) dengan world without secrets bahwa kehadiran media baru (new media/cybermedia) menjadikan informasi sebagai sesuatu yang mudah dicari dan terbuka.

Fungsi-fungsi media sebagaimana selama ini didapat dari media tradisional, juga telah bertambah bisa didapat dari internet. Misalnya, media televisi menyediakan program yang bertujuan membuat penonton terhibur. Kehadiran YouTube memberikan alternatif pilihan untuk menyaksikan tayangan audio-visual yang bisa bersaing dengan program televisi tersebut. Tidak hanya itu, waktu yang disediakan, sumber tanpa batas, serta bisa diakses kapan dan dimana saja, menyebabkan kehadiran internet dan media-media di dalamnya, seperti media sosial (social media), menjadi lebih mendominasi.

Tidak mengherankan, kehadiran media sosial menjadi fenomenal. Facebook, Twitter, Youtube, Instagram hingga Path adalah beberapa jenis media sosial yang diminati banyak

\footnotetext{
${ }^{1}$ Dian Muhtadiah Hamna, Staf Pengajar Prodi Ilmu Komunikasi Fisipol Universitas Muhammadiyah Makassar, Mantan Jurnalis dan Editor Harian Fajar (Jawa Pos Group), anggota AJI Makassar.
} 
khalayak. Media sosial tidak hanya digunakan untuk mendistribusikan informasi yang bisa dikreasikan oleh pemilik akun (users) itu sendiri, tetapi juga memiliki dasar sebagai portal untuk membuat jaringan pertemanan secara virtual dan medium untuk berbagi data, seperti audio atau video.

Jumlah pengguna ponsel di seluruh dunia pada akhir tahun 2012, menurut International Telecommunications Union, mencapai 6,8 miliar, melesat dibanding 5,4 miliar pada tahun 2010. Sedikitnya terdapat 100 negara yang jumlah ponselnya melebihi jumlah penduduknya. Salah satunya, Indonesia yang kini berada di posisi keempat dalam jumlah ponsel dunia, di bawah China, India, dan Amerika Serikat. Jumlah pelanggan ponsel di Indonesia per Desember 2012, menurut mobiThinking, mencapai 260 juta, sementara jumlah penduduk Indonesia tercatat 242, 3 juta. Hal ini berarti jumlah ponsel yang beredar lebih tinggi daripada jumlah penduduk negeri (107,3 persen). Dari jumlah tersebut, sebanyak 47,6 juta atau 19 persen pengguna 3G/3,5 G. (Kompas, 28 Juni 2013).

Mengutip data yang dirilis ComScore, Februari 2012, Keith Lin, pengajar pada Nanyang Technological University (NTU) Singapura menyebutkan 33 persen pengguna jejaring sosial di dunia berada di kawasan Asia Pasific, sementara di Eropa 30 persen, Amerika Utara 18 persen, Amerika Latin 10 persen, dan sisanya di Kawasan Timur Tengah dan Afrika yang hanya 9 persen. Dalam tiga bulan terakhir tahun 2012, sebanyak 43,8 juta penduduk Indonesia termasuk pengguna jejaring sosial Facebook. Hal ini telah menempatkan Indonesia pada urutan keempat di dunia dalam penggunaan Facebook setelah Amerika, Brasil dan India. Demikian pula dalam penggunaan Twitter, saat ini Indonesia masuk dalam lima besar pengguna jejaring sosial tersebut. (Kompas, 28 Juni 2013).

Terkait perkembangan ini, Dewan Pers mengadakan survei untuk mengetahui kecenderungan penggunaan konten media sosial dalam peliputan dan produksi berita oleh wartawan. Survei diadakan pada 29 November 2011-3 Februari 2012, melibatkan 157 responden yang semuanya berprofesi wartawan. Hasil survei menyebutkan bahwa sebanyak 96 persen responden memiliki akun Facebook, 67 persen memiliki akun Twitter, 40 persen memiliki blog/Wordpress, 22 persen memiliki Linkedin, dan lain-lain (9 persen).

Sebanyak 76 responden menjawab informasi di media sosial dipakai sebagai sarana memantau, 46 persen sebagai sumber ide berita, dan mencari narasumber 31 persen. Sebanyak 75 persen responden menjawab selalu melakukan verifikasi ulang dengan mengontak orang 
yang pesannya dikutip di media sosial. Sebanyak 14 persen responden mengaku sebagian diverifikasi ulang. (Kompas, 18 Februari 2012).

\section{Pembahasan}

Pesatnya perkembangan media sosial saat ini karena semua orang seperti memiliki medianya sendiri. Definisi media sosial adalah medium di internet yang memungkinkan pengguna merepresentasikan dirinya maupun berinteraksi, bekerja sama, berbagi, berkomunikasi dengan pengguna lain, dan membentuk ikatan sosial secara virtual. (Nasrullah, 2015: 11).

Kehadiran media sosial juga menjadi tantangan bagi media konvensional, seperti koran, televisi, dan radio. Kecepatan informasi dari media sosial biasanya lebih cepat dibandingkan dengan media konvensional. Hal ini dimaklumi karena memang jurnalisme harus mengedepankan check and recheck.

\section{Pedang Bermata Dua}

Media sosial ibarat bermata dua. Pengaruhnya bisa menjadi positif dan produktif, tetapi bisa juga negatif dan kontraproduktif. Media sosial yang memproduksi ujaran kebencian, menyebarkan informasi bohong, merupakan terorisme verbal yang menciptakan kekhawatiran dan ketidakpastian. Setelah 71 tahun merdeka, bangsa Indonesia memasuki euforia kebebasan berekspresi di media sosial. Presiden RI, Joko Widodo mulai mempertanyakan ujaran kebencian, adu domba yang merebak di media sosial.

Jumlah pengguna internet di Indonesia hingga Juni 2015, mencapai 73 juta atau 28,5 persen dari penduduk Indonesia. Pengguna Facebook berjumlah 51.096 .860 akun per 31 Desember 2012. Seiring dengan dinamika politik Indonesia, linimasa media sosial mulai merambah isu politik yang sangat rawan. Linimasa merupakan loncatan besar dalam demokrasi karena menciptakan ruang tanpa batas untuk mengekspresikan pandangan politik. Linimasa memotong hierarki informasi yang selama ini berjenjang. (Kompas, 22 November 2016).

Kerusuhan di Tanjung Balai, Jumat-Sabtu, 29-30 Juli 2016 adalah akibat dari status seseorang di media sosial yang berujung pada kerusuhan. Hal ini menjadi contoh wajah lain dari pengaruh negatif dan kontraproduktif media sosial di Indonesia. Peristiwa di Tanjung Balai, Sumatera Utara, berawal dari teguran seorang warga di Kelurahan Indra Sakti, 
Kabupaten Tanjung Balai, terhadap seorang pengurus masjid terkait pengeras suara masjid yang tidak jauh dari rumahnya.

Kepala Polisi Jenderal RI (Pol) Tito Karnavian menilai penyebaran ujaran kebencian di media sosial menjadi salah satu faktor yang mempercepat eskalasi konflik. Media sosial memang memungkinkan setiap orang menjadi "produsen" informasi. Tidak hanya itu, orang yang mendapat informasi "setengah matang" pun bisa membagikan informasi tersebut dengan tambahan informasi yang belum tentu benar. Jejak-jejak ujaran kebencian berselang dua hari peristiwa tersebut masih bisa ditemui di beberapa akun Facebook jika mengetik kata kunci "Tanjung Balai" atau "Tanjung Balai Rusuh" di alat pencari yang disediakan situs jejaring pertemanan. Baik foto maupun gambar rumah ibadah yang dibakar di Tanjung Balai yang diunggap beberapa netizen.

Wacana pembangkit kebencian yang diunggah ke media sosial sebelum pecahnya kerusuhan sudah sukar dicari. Boleh jadi karena sebagian sudah dihapus. Namun penegak hukum masih bisa melacaknya lewat forensik digital.

Swati Bute dalam buku The Role of Social Media in Mobilizing People for Riots and Revolutions: Four Case Studies in India (2014) menggunakan kasus kerusuhan di Assam tahun 2012 dan Muzzafarpur tahun 2013 untuk menganalisis sumbangsih media sosial dalam kerusuhan. Dalam dua kerusuhan yang menewaskan puluhan orang itu, Swati menemukan adanya rangkaian pesan yang menyesatkan dan gambar-gambar palsu yang menyebar di telepon pintar. Swati berpendapat, sebagian informasi yang beredar di media sosial masih bersifat "setengah matang". Ironisnya, dibanding berupaya mencari informasi pembanding, sebagian besar netizen lebih tertarik mengomentari informasi apa pun yang mereka dapat tanpa mengetahui validitasnya.

Pendiri Forum Demokrasi Digital yang juga Koordinator Regional The South East Asia Freedom of Expression Network (Safenet), Damar Juniarto mengatakan, ketika menjelang dan saat kerusuhan berlangsung di Tanjung Balai, tidak muncul wacana "damai" untuk mengimbangi pesan-pesan kebencian. Akibatnya, masyarakat mendapat pasokan informasi searah yang sebagian merupakan reproduksi informasi yang tidak akurat sehingga semakin membakar kemarahan. (Kompas, 2 Agustus 2016).

\section{Dipadati Berita Abal-abal}


Sebagian besar artikel yang beredar di jejaring media sosial adalah artikel dengan judul yang tidak jelas, bombastis dan "murahan". Sebagian besar artikel tersebut berisi informasiinformasi palsu yang asal dibagikan tanpa konfirmasi dan verifikasi. Pakar Media Sosial, Nukman Luthfie mengatakan, membagikan informasi-informasi palsu tersebut merupakan karakter masyarakat digital. Melalui situs http://buzzsumo.com, misalnya, bisa terpantau bagaimana peredaran berita-berita berjudul bombastis di media sosial. Bahkan, sebagian besar berita dengan judul tidak jelas banyak dibagi oleh portal-portal yang tidak jelas atau media abal-abal. (Kompas, 25 November 2016).

Fenomena seperti ini tidak hanya terjadi di Indonesia, tetapi juga di beberapa negara lainnya. Menjelang pemilihan presiden Amerika Serikat beberapa waktu lalu, berita-berita yang paling banyak beredar di media sosial Amerika Serikat adalah berita abal-abal. Minimnya literasi digital juga dialami negara maju yang masyarakatnya berpendidikan tinggi. Sekitar 59 persen konten yang dibagikan di media sosial tidak pernah di-klik atua dibuka, tetapi hanya dibaca sepintas lalu. Bahkan dengan kecenderungan ini, karena tuntutan bisnis media-media online mainstream akhirnya mengikuti arus dengan membuat berita-berita berjudul bombastis. Sementara itu, media-media online dengan konten-konten mendalam dan serius justru cenderung tidak laku dibaca.

Terlebih, di dalam media sosial tidak ada prosedur penyaringan layaknya di media konvensional (arus utama) seperti koran, majalah, radio, dan televisi. Segala jenis konten langsung ditampilkan apa adanya, bahkan banyak yang telah dibumbui demi sensasi. Banjir informasi di media sosial mengarahkan netizen justru mencari konten yang membenarkan pemikirannya, bukan yang memberi sudut pandang berbeda.

Psikolog Sosial Universitas Indonesia, Roby Muhammad mengatakan media sosial mengerdilkan kemampuan seseorang melakukan kontestasi ide karena penalaran digunakan untuk mencari pembenaran, bukan kebenaran. Pendapat serupa dikemukakan peneliti Pusat Studi Pendidikan dan Kebijakan yang juga Psikolog Pendidikan Universitas Surabaya, Anindito Aditomo. Kurangnya kemauan untuk mencari verifikasi atas berita yang didapat di media sosial juga disebabkan kurangnya literasi digital.

Minimnya sikap skeptis dan kritis selama ini mengakibatkan segala sesuatu ditanggapi secara emosional. Ekspresi di media sosial jauh lebih ekstrem daripada yang bisa diungkapkan secara langsung di depan umum karena tidak harus berhadapan dengan 
khalayak di dalam ruang fisik yang sama. Kemauan untuk menggali informasi lebih lanjut lebih penting daripada memiliki kemampuan analisis. (Kompas, 23 Desember 2016).

Penyesuaian tersebut dilakukan dengan cara membuat media konvensional menjadi lebih interaktif, lebih instan, dan bisa menyampaikan informasi dengan cepat tanpa mengorbankan akurasi. Pertanyaannya, mampukah jurnalisme bertahan di era media sosial? Betulkah media sosial justru akan membunuh jurnalisme?

\section{Jurnalisme dan Media Sosial}

Pertengahan Juli 2012 lalu, tidak kurang dari 55 pemimpin redaksi dari sejumlah media berkumpul dan mendeklarasikan berdirinya Forum Pemred. Ketua Pengurus Harian Forum Pemred, Wahyu Muryadi menegaskan, forum yang dibentuknya bersama puluhan pemred media massa itu bebas dari berbagai kepentingan. Pemimpin Redaksi Tempo ini mengatakan, tantangan paling konkret Forum Pemred tersebut adalah bagaimana mengembalikan esensi jurnalisme, informasi berkualitas, dan pengabdian kepada publik yang menjadi tujuan akhir media-media. Pers yang bebas atau independen dari pengaruh kekuasaan, baik ekonomi maupun politik semakin sedikit dan pada akhirnya publik yang akan mengalami kerugian itu. (Kompas, 28 Juli 2012).

Kerugian timbul apabila pemberitaan yang muncul dari pelbagai outlet media sering tampil secara bias, mengesampingkan isu-isu penting untuk publik, tetapi mengedepankan kepentingan para pemilik media. Belum lagi isi media makin menghindar dari risiko menjadi jurnalisme yang baik, mengurangi upaya melakukan kerja jurnalisme investigasi.

Media sosial yang muncul belakangan ini memang mengubah panorama jurnalisme di Indonesia. Terutama yang menyangkut proses pengumpulan berita, proses pembuatan berita, dan proses penyebaran berita.

Dalam proses pengumpulan berita, sudah menjadi umum saat ini jika "status" yang ditunjukkan oleh para orang terpandang-ataupun orang orang yang biasa jadi narasumberdalam aneka media sosial mereka bisa menjadi bahan, yang kemudian ditulis di media massa mainstream. Sementara itu, aneka "informasi" yang tersebar dalam jejaring media sosial juga sering menjadi informasi yang kemudian disebarkan oleh media massa mainstream. Dalam hal ini, jurnalisme warga memiliki ruang untuk beritanya makin tersebar. 
Sementara dalam proses pembuatan berita, sekarang pun sudah menjadi sesuatu yang umum ketika media online yang menampilkan jurnalisme memberikan ruang komentar dari para pembacanya atas item berita yang mereka hasilkan. Dalam proses penyebaran berita, aneka tampilan media sosial dipergunakan baik oleh media itu sendiri maupun para pembacanya untuk meneruskan berita yang telah diproduksi. Di sini terlihat pembaca atau konsumen media yang memiliki perilaku senang berbagi dalam suasana media yang makin konvergensi. (Henry Jenkins, Convergence Culture: Where Old and New Media Collide, 2006 dalam Kompas, 24 September 2011).

Banyak pihak melihat jurnalisme dan media sosial sebagai sesuatu yang sedang popular dan perlu terus dipromosikan. Namun, tidak semua orang melihat kedua hal tersebut sebagai sesuatu yang saling menguntungkan. Robert G Pichard, misalnya dalam artikelnya di Nieman Reports (Musim Gugur, 2009) justru mempertanyakan manfaat dari media sosial terhadap perusahaan media secara umum. "Hanya karena teknologi itu popular untuk kalangan jurnalis dan penggunanya, itu bukan berarti penggunaan teknologi itu lalu menguntungkan perusahaan media secara keseluruhan".

Pertanyaan mendasar: apakah sikap masyarakat yang mudah berbagi informasi tidak sedang turut berpartisipasi dalam mengkreasi kecemasan missal ataupun kebohongan bersama? Di sini, unsur dasar jurnalisme dibutuhkan yakni verifikasi. Di sini peran wartawan tetap diperlukan. Wartawan harus bisa memverifikasi informasi sebelum tersebar luas agar tidak terjadi kebingungan di kemudian hari. (Haryanto, 2014: 10).

Namun pada kenyataannya, kecepatan untuk melakukan verifikasi kalah cepat dengan tersebarnya informasi tersebut ke berbagai arah. Lalu, apakah koreksi atau imbangan informasi yang menyusul akan bisa mengalahkan kecepatan penyebaran berita terdahulu? Pertanyaannya: apakah ini kondisi yang adil? Jika tidak, bagaimana jurnalisme masa kini menangani hal tersebut? Persoalan mendasar adalah seberapa banyak isi dari jurnalisme mengisi media sosial yang ada? Bagaimana membedakan jurnalisme dengan isi media lain seperti gosip, tips, hingga berita yang dikreasi untuk tujuan tertentu oleh pihak-pihak tertentu? Betulkah jurnalisme masih dominan dalam era media sosial? Bill Kovach dan Tom Rosenthiel jauh-jauh hari mengingatkan hal ini sebagai elemen pertama dan mendasar dalam Elements of Journalism yang terdiri sembilan butir:

1. Kewajiban pertama jurnalisme adalah pada kebenaran 
2. Loyalitas pertama jurnalisme adalah kepada masyarakat

3. Intisari jurnalisme adalah disiplin verifikasi

4. Praktisi jurnalisme harus menjaga independensi terhadap sumber berita

5. Jurnalisme harus menjadi pemantau kekuasaan

6. Jurnalisme harus menyediakan forum kritik maupun dukungan masyarakat

7. Jurnalisme harus berupaya keras untuk membuat hal penting menarik dan relevan

8. Jurnalisme harus menyiarkan berita komprehensif dan proporsional

9. Praktisi jurnalisme harus diperbolehkan mengikuti nurani mereka

Jurnalisme hadir untuk membangun masyarakat. Jurnalisme ada untuk memenuhi hak-hak warga negara. Jurnalisme ada untuk demokrasi. (Kovach\&Rosenstiel, 2006: 11). Jutaan orang, yang terberdayakan arus informasi bebas, menjadi terlibat langsung dalam menciptakan pemerintahan dan peraturan baru untuk kehidupan politik, sosial, dan ekonomi negara mereka. Apakah ini selalu menjadi tujuan jurnalisme? Ataukah hal ini hanya tepat di satu momen, di sebuah tempat tertentu?

Namun, tujuan jurnalisme tidaklah ditentukan oleh teknologi atau wartawan maupun teknik yang dipakai. Prinsip dan tujuan jurnalisme ditentukan oleh sesuatu yang lebih mendasar-fungsi yang dimainkan berita dalam kehidupan masyarakat.

Belum banyak wajah jurnalisme yang berubah tetapi secara mengagumkan tujuannya tetap terjaga — yakni, menyediakan informasi yang dibutuhkan warga agar mereka bisa hidup bebas dan mengatur diri sendiri-walaupun tak selalu tersaji dengan baik, mengingat pengertian "pers" pertama kali berkembang lebih dari 300 tahun yang lalu. Sekali pun semuanya telah berubah-kecepatan, teknik, karakter pengiriman berita-teori dan filosofi yang gamblang tentang jurnalisme tetap bertahan.

Masih banyak persoalan lain yang ditemui dalam melihat persoalan antara jurnalisme dan media sosial. Namun, ini memang suatu pertanda munculnya era baru dalam dunia media komunikasi, menantang masyarakat untuk lebih mendalaminya, dan mencoba memahami serta kembali pada esensi utamanya: untuk apa komunikasi diciptakan? Untuk memudahkan manusia berhubungan dengan manusia lain, untuk lebih "memanusiakan manusia" atau malah menghasilkan dehumanisasi?

\section{Jurnalisme Era Baru}


Pada pemilihan presiden tahun 2008, video yang dibuat staf kampanye Obama disaksikan lebih dari 1 miliar kali di You Tube milik sang kandidat, tanpa melibatkan pers. Sepertiga orang Amerika kini membaca berita berkat rekomendasi sosok nonwartawan yang mereka ikuti di jejaring sosial. Hampir separuh dari seluruh orang Amerika menyaksikan atau membaca berita yang dikirim dari email. Enam dari sepuluh orang yang online memeroleh berita dari mesin aggregator. Sepertiga dari online membaca blog dan enam dari sepuluh orang menyaksikan video dari situs seperti You Tube. Dan, teknologi serupa yang mempermudah warga memproduksi konten mereka sendiri juga dimanfaatkan pemerintah, swasta atau entitas lain untuk berkomunikasi langsung. Di tengah kondisi ini, wartawan pun menjadi penjaga pintu untuk ruangan yang tidak lagi berdinding.

Lantas, peran apa yang mesti dimainkan wartawan? Jika kini warga menjadi editor, kadang bahkan reporter untuk diri sendiri, lalu apa yang mereka perlukan dari pers? Bagaimana pencarian dan penyebaran berita berjalan, siapa yang akan memproduksi, dan bagaimana ia dikonsumsi? Dengan kata lain, apa yang diperlukan dari sesuatu yang disebut sebagai "jurnalisme era baru?"

Para ahli telah menawarkan berbagai respons. Banyak dari mereka menilai jurnalisme mesti menjadi sebuah dialog, bukan ceramah. Yang lain berpendapat lebih jauh dengan menganggap bahwa saat ini, masyarakat tidak perlu lagi wartawan karena kini masyarakat hidup di era semua orang bisa menjadi wartawan dan kebenaran bisa ditemukan lebih efektif bukan dari beberapa tetapi 1.000 suara-dalam pandangan ini, berita menjadi sejenis akun Wikipedia yang selalu berubah bersamaan dengan kejadian hari itu. Masih ada juga yang menilai bahwa masyarakat mesti membuang ide usang yang gagal soal objektivitas, dimana wartawan menipu diri dengan berpikir mereka bukanlah makhluk tanpa bias.

Oleh karena itu, jawabannya adalah kombinasi jurnalisme lama dan baru: fungsi pers sebagai penjaga pintu tak menghilang sepenuhnya, melainkan hanya mengecil dimensinya tentang apa yang mesti disediakan pers, dan dengan sendirinya tak cukup menjelaskan peran pers. Pers harus menampilkan seperangkat fungsi yang lebih kompleks dari sekadar penjaga pintu dan mengadopsi format baru gaya bertutur, penyebaran dan pelibatan public dalam berita. Pers masih menjadi mediator, tetapi dengan peran mediasi yang lebih beragam dan kompleks, dan menjalankannya di dunia komunikasi tanpa batas seperti sekarang akan lebih sulit. (Kovach dan Rosentiels, 2012: 180). 
Objektivitas tidak berarti netral. Maksud sebenarnya adalah pers mesti melakukan metode objektif dan transparan dalam mengumpulkan dan memverifikasi berita, definisi ini lebih dekat pada "objektivitas" dalam pengetahuan. Kini, seiring dengan konsumen yang makin kuat dan pemilih, elemen-elemen itu tetap relevan. Teknologi mungkin mengubah cara pengiriman dan bentuk berita, dan menciptakan dorongan ekonomi berbeda di antara orang atau perusahaan yang menggeluti pers, tetapi ia tidak akan mengubah sifat dasar manusia dan nilai penting atas apa yang perlu diketahui orang. Isu yang lebih mendesak adalah bagaimana jurnalisme berubah untuk menjaga nilai-nilai itu di era baru.

Langkah pertama adalah memahami cara baru memeroleh berita. Masyarakat kini bersandar pada beberapa otoritas baru untuk memberi tahu apa yang penting. Masyarakat mendapat email, mendapat berita dari sumber non berita di jejaring sosial, membaca blog, memilah melalui agregator dan lain-lain. Perilaku baru ini hanyalah satu di antara banyak perubahan besar.

Ceruk atau situs berita khusus kurang popular dibandingkan dengan situs topik umum, dan rata-rata orang mengunjungi situs khusus separuh dari biasanya dan waktu kunjungannya juga separuh lebih sedikit. Dengan kata lain, berbalik dari perkiraan banyak orang, analisis lebih dekat atas data keras itu menunjukkan bahwa konsumen masih mengingingkan nilai dan sumber berita tradisional. Dan mereka masih menginginkan etalase berisi berbagai subjek berita. Perbedaannya hanya pada cara mereka menuju sumber berita. Masyarakat berada di budaya konsumen berita berbasis permintaan, yang mengakses apa yang diinginkan kapan pun.

Oleh karena itu, pekerja pers harus mengganti ide tunggal dari pers sebagai penjaga pintu satu-satunya menjadi ide variatif yang lebih baik berdasarkan keperluan konsumen akan berita-khususnya berita mendalam, ketimbang sekadar komentar dan diskusi. Jurnalisme masa depan — yang lama dan yang baru-harus mengacu pada bagaimana orang menggunakan berita dan apa yang mereka butuhkan dari wartawan. Ada delapan ukuran dan fungsi penting jurnalisme yang dibutuhkan konsumen berita sekarang Delapan fungsi tersebut menggambarkan ide jurnalisme sebagai layanan dialog. Kedelapannya adalah: 


\section{- Otentikator (Pensahih)}

Masyarakat membutuhkan pers untuk membantu mensahihkan fakta yang benar dan dapat dipercaya. Meski masyarakat tidak melihat wartawan sebagai penyedia informasi tunggal, tetapi tetap perlu tahu beberapa cara membedakan informasi mana yang bisa dipercaya dan beberapa bukti dasar mengapa demikian. Peran penyahih akan jadi utama dalam ruh pembangunan otoritas perusahaan media dan juga elemen kunci yang relevan ketika mereka tak lagi memonopoli arus informasi atau perhatian publik.

\section{- Sense Maker (Penuntun Akal)}

Jurnalisme juga sangat cocok memainkan peran penuntun akal—untuk meletakkan informasi pada konteks dan mencari kaitannya hingga konsumen bisa memutuskan apa makna berita itu. Membangun makna tidak sama dengan menginterpretasi berita. Semua bisa saja memaknai sendiri. Namun upaya membangun makna mensyaratkan pencarian keterkaitan antarfakta untuk membantu menjawab pertanyaan masyarakat. Wartawan verifikasi mesti membantu melakukan ini.

\section{- Investigator}

Wartawan juga harus melanjutkan fungsi sebagai investigator publik, yang banyak diistilahkan sebagai peran anjing penjaga. Jurnalisme yang mengekspos apa saja yang disembunyikan atau dirahasiakan menjadi begitu penting dan esensial di pemerintahan demokratik, hingga nilai pentingnya begitu fundamental bagi jurnalisme baru dan lama.

\section{- Witness Bearer (Penyaksi)}

Tak semua cahaya yang disorotkan pers mengekspos pelanggaran, ada sesuatu yang kuat dan esensial, tapi kurang diperhatikan, dalam pers dengan sekadar mengada dan jadi saksi kejadian. Ini adalah fungsi pengawasan jurnalisme, di tingkat yang lebih ramah dari fungsi anjing penjaga atau investigator. Ada hal tertentu di komunitas yang harus diamati, diawasi, diteliti. Jika tidak, pemerintah dan pihak yang ingin mengeksploitasi akan mengedepankan kepentingan pribadi daripada kebaikan publik. Di era baru sekarang, pers yang lemah tak boleh merajalela. Minimal mengenali tempat yang mesti diawasi dalam 
komunitas demi keutuhan dasar masyarakat sipil, dan hadir yang dengan kehadirannya itu mengisyaratkan pesan kepada penguasa bahwa mereka diawasi.

\section{- Pemberdaya}

Pers harus menempatkan publik sebagai bagian dari proses berita dan bukan cuma audiens. Ini adalah pemberdayaan timbal balik. Warga diberdayakan untuk membagi pengalaman dan pengetahuan yang informative pada pihak lain - termasuk wartawan. Para wartawan diberdayakan dengan mengejar pengalaman dan keahlian di luar sumber formal dan resmi mereka. Kemitraan ini menguntungkan bagi warga dan wartawan. Dialog dikembangkan, membuat saling memahami proses, dan bukannya produk. Wartawan dan warga harus saling menghormati. Warga harus mengakui bahwa jurnalis berdedikasi mengejar fakta dan coba menyajikannya untuk membantu mereka menyimpulkan sendiri. Dan wartawan, baik di ruang redaksi lama atau pun baru, harus menghormati kapasitas warga memahami informasi dan menyikapinya.

\section{- Agregator Cerdas}

Pers juga perlu bantuan memanfaatkan kekuatan web. Pers butuh agregator pintar yang menyisir web untuk membantu tugas-tugas jurnalis melampaui kemampuan algoritma komputer dan agregator umum. Organisasi berita masa depan mesti menyisir lanskap informasi, mewakili audiens melakukan pengawasan atas informasi lain yang mungkin membantu. Ide dari "ruang berpintu" dimana cuma perusahaan media yang menyajikan liputan, sudah mati. Agar perusahaan media bisa benar-benar membantu, melayani konsumen berita yang berorientasi ke depan, ia mesti juga mengarahkan audiens ke sumber web lain yang dinilai penting. Inilah yang membuat web kuat. Agregator cerdas membagi sumber yang dirujuk, kisah yang menurut mereka mencerahkan, berita informatif, mengefisienkan waktu pembaca dan mengarahkan mereka ke sumber terpercaya.

\section{- Penyedia Forum}

Para wartawan, khususnya yang lokal, juga mesti membantu terbentuknya diskusi dan wacana yang melibatkan warga secara aktif. Lembaga berita milik komunitas, bisa menjadi 
ruang terbuka bagi warga untuk memonitor suara dari berbagai sisi, bukan hanya dari mereka yang berideologi sama dengan jurnalis. Sebagai warga, semua punya hak mempunyai ruang public yang terbuka bagi siapa pun. Jika praktisi media membayangkan bahwa tujuan mereka adalah menginspirasi dan menginformasikan wacana publik, maka membantu mengorganisir wacana tersebut adalah fungsi logis dan layak. Institusi berita mendalam adalah yang paling pas mengorganisir forum publik yang berdasarkan informasi terpercaya.

\section{- Panutan}

Pers era baru, khususnya yang terkait dengan perusahaan media lama, jika masih bertahan, tak bisa mengelak dari fungsi sebagai role model (panutan) bagi warga yang ingin membawa kesaksiannya sendiri dan sekaligus bertindak sebagai wartawan warga. Tak pelak lagi, mereka akan berkaca pada wartawan untuk melihat bagaimana pekerjaan ini dilakukan, meniru apa yang mereka lihat dan sukai, dan meninggalkan apa yang mereka tidak sukai. Beberapa perusahaan media telah melangkah jauh dengan menyediakan pelatihan jurnalisme warga dan mengundang mereka dalam rapat redaksi. Namun, perlu ada sesuatu yang lebih. Wartawan mesti paham bahwa tingkah laku mereka-bukan cuma berita mereka-dilihat publik. Pada satu titik (yang tidak mungkin dipahami konsultan pemasaran dan merek), publik telah menangkap sinisme dan keburukan di balik slogan "memihak Anda" atau "untuk mengabdi pada Anda" dan sebagainya. Penurunan rasa hormat publik itu tercermin dari turunnya tingkat kepercayaan terhadap pers dalam 30 tahun terakhir. Di era digital yang kian terbuka, pers yang tak menjaga klaim konstitusionalnya hanya akan makin mengecewakan, karena publik mengukur kinerja mereka berdasarkan harapan yang terbaik, dan bukannya terburuk pada jurnalisme.

\section{Etika Jurnalisme dan Tantangan Masa Kini}

Menurut Ward dalam Zulkarimein Nasution (2015: 164), etika tradisional yang dulu dominan dan dibangun untuk jurnalisme profesional satu abad silam, kini dipertanyakan. Etika jurnalisme menjadi ajang dimana nilai-nilai lama berhadapan dengan nilai-nilai baru. Di satu sisi ada nilai-nilai tradisional seperti yang terkandung dalam kode etik organisasi junalis seperti Society of Professional Journalist di Amerika Serikat. Di situ dicantumkan 
perihal suatu komitmen kepada profesionalisme, pemisahan berita dengan opini, metode untuk memverifikasi fakta, concern mengenai akurasi, objektivitas sebagai ideal dan meminimalisasi kecederaan.

Di sisi lain, jurnalisme masa kini mencerminkan adanya nilai-nilai baru seperti kesemestaan media interaktif (universe of interactive media) yang "always on" dan dicirikan oleh:

- Kesegeraan (immediacy)

- Transparansi (transparency)

- Edgy opinion dan jurnalisme partisan

- Anonimitas (anonymity)

- Saling berbagi content (sharing)

Kecepatan media baru dalam menyiarkan informasi telah menggoda banyak penggunanya untuk mengabaikan metode pembatasan (restricting methods) akurasi dan verifikasi yang merupakan esensi dari etik jurnalisme. Di samping itu, ada beberapa faktor lain ikut menjadi penyebab. Salah satu alasan yang sering dikemukakan umumnya menyangkut situasi dan krisis finansial yang dihadapi oleh perusahaan media sebagai imbas dari kondisi perekonomian global yang mengalami krisis. Kata Jim Boumelha, Presiden International Federation of Journalist, krisis tersebut telah menggulung media di Eropa dan Amerika yang lantas menyulut perubahan besar dalam jurnalisme.

Seberat apapun tantangan yang dihadapi, satu hal yang pasti bahwa jurnalisme harus tetap menjunjung tinggi dan mempraktikkan etika. Presiden International Federation of Journalist, Jim Boumelha menegaskan bahwa: "Ini merupakan penyemangat (encouragement) bagi mereka yang siap untuk menegakkan jurnalisme dan konfirmasi, di abad konvergensi ini media tradisional dan media baru, bahwa jurnalisme sebagai suatu public good tidak akan survive pada platform mana pun tanpa komitmen pada etika dan nilainilai.

\section{Kesimpulan}

Jurnalisme di era media sosial adalah keniscayaan. Tanpa jurnalisme, informasi yang tersiar dalam ranah publik akan menjadi bias. Di era banjir informasi dan semua orang bisa mengklaim diri sebagai "jurnalis", di sinilah jurnalisme verifikasi dibutuhkan. Seberat 
apapun tantangan yang dihadapi termasuk perubahan teknologi yang menuntut kecepatan menyebarkan informasi, jurnalisme harus tetap menjunjung tinggi dan mempraktikkan etika.

Praktisi media mesti secara profesional juga memikirkan "bagaimana perubahan cara mengkonsumsi berita" bagi warga. Kini, mereka tak cukup hanya menyajikan berita tiap hari tentang subjek yang dianggap terpenting. Mereka mesti paham tujuan yang dimiliki masing-masing berita untuk audiens, pelayanan apa yang mesti disediakan atau pertanyaan apa yang mesti dijawab.

Di balik visi jurnalisme sebagai pelayan yang kian kompleks dan berkembang, ada teknologi baru yang sangat membantu pers dan perlu dikembangkan. Teknologi secara drastis memberi tanggung jawab dan kapasitas lebih bagi pencari berita. Internet tidak hanya menciptakan jurnalisme baru, tetapi membuat jurnalisme lebih baik yang menggali dan bersinggungan dengan publik lebih dalam. Dengan kata lain, jurnalisme tidak menjadi usang. Ia hanya menjadi lebih rumit. (*)

\section{DAFTAR PUSTAKA}

\section{A. Buku}

Haryanto, Ignatius. 2014. Jurnalisme Era Digital; Tantangan Industri Media Abad 21. Jakarta: Kompas

Kovach, Bill dan Tom Rosenstiel. 2006. Sembilan Elemen Jurnalisme. Jakarta: Yayasan Pantau

Kovach, Bill dan Tom Rosenstiel. 2012. Blur; Bagaimana Mengetahui Kebenaran di Era Banjir Informasi. Jakarta: Dewan Pers

Nasrullah, Rulli. 2015. Media Sosial: Perspektif Komunikasi, Budaya dan Sosioteknologi. Bandung: Simbiosa Rekatama Media

Nasution, Zulkarimein. 2015. Etika Jurnalisme; Prinsip-prinsip Dasar. Jakarta: PT RajaGrafindo Persada

\section{B. Koran}

Kompas, ed. 24 September 2011 , ed. 18 Februari 2012 , ed. 28 Juli 2012 , ed. 28 Juni 2013 ,ed. 2 Agustus 2016 , ed. 22 November 2016 , ed. 25 November 2016 , ed. 23 Desember 2016 